
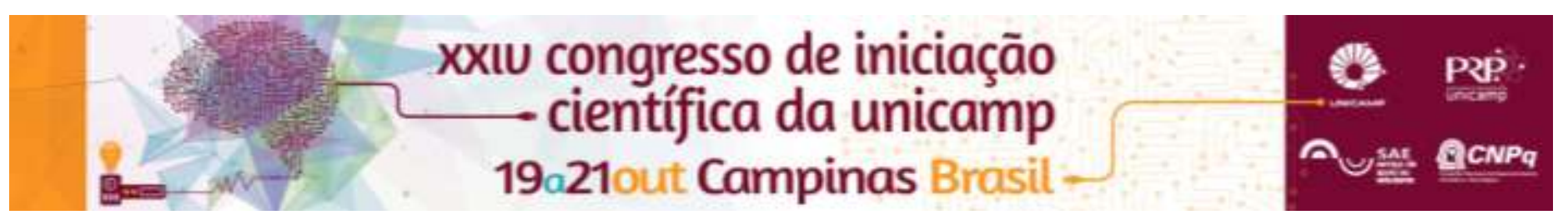

\title{
Relação professor supervisor e aluno de Iniciação à Docência no contexto das atividades do Pibid
}

\author{
Jéssica S. R. Cecim
}

\section{Resumo}

Este trabalho se enquadra na área de Ensino de Geografia e é fruto de uma pesquisa em andamento. Seu objetivo é a compreensão da relação existente entre o professor supervisor e o aluno bolsista de Iniciação à Docência no contexto do desenvolvimento das atividades do Pibid no subprojeto Geografia - Unicamp. A ideia central é a de que ambos os sujeitos, estando em espaçostempo de formação distintos, se influenciam mutuamente em sua formação docente. O Programa Institucional de Bolsa de iniciação à Docência (Pibid) surge em 2007 em um contexto de uma série de transformações propostas pelo MEC. Visa à formação de professores da educação básica e relaciona, dessa forma, educação básica e ensino superior. O subprojeto Geografia - Unicamp existe desde 2011 e desenvolve diversas atividades nas escolas de ensino básico participantes do programa e na universidade. Metodologicamente, a pesquisa qualitativa em educação por meio do estudo autobiográfico foi considerada a melhor maneira de sistematizar este trabalho, o que também nos leva à utilização das escritas narrativas para compor o texto. Entrevistas com o professor supervisor e demais pibidianos também foram consideradas primordiais para o desenvolvimento da pesquisa. Até o presente momento foram realizadas as etapas empíricas, como as observações ocorridas na escola e as entrevistas. Desde o inicio da pesquisa até o estágio atual tem sido realizado o levantamento bibliográfico norteador de meus escritos, que se baseia, sobretudo, na instituição do Pibid enquanto Política Educacional; na Formação Docente - tendo como referência autores como António Nóvoa, Selma Garrido Pimenta, Maurice Tardif, Stuart Hall, entre outros - e a Teoria do Discurso de Enersto Laclau e Chantal Mouffe.Espera-se que até o final deste trabalho possamos compreender uma das possibilidades de formação docente proporcionado por esse programa dentro do contexto do subprojeto Geografia - Unicamp.

\section{Palavras-chave}

Formação Docente, Teoria do Discurso, Pibid.

\section{Introdução}

O Pibid é um programa instituído em 2007 com o objetivo de promover a valorização das licenciaturas por meio da interação com as escolas de ensino básico. Dentro deste programa dois sujeitos são destacados nessa pesquisa: o professor supervisor e o aluno bolsista de Iniciação à Docência. O primeiro se encontra em sua Formação Continuada, ao passo que o segundo em Formação Inicial.

O objetivo deste trabalho é compreender como esses particularismos se relacionam no cotidiano das atividades do subprojeto Geografia - Unicamp e, de modo geral, como se influenciam em seus percursos formativos. Para tal, é trazido ao debate enquanto método os conceitos da Teoria do Discurso, como particularismo, universalismo, corte antagônico, discurso hegemônico e significante vazio. Enquanto metodologia foi realizada uma aproximação com os estudos autobiográficos, visto que ao pesquisar o Pibid também me coloco na categoria de pesquisada e, portanto, trago a todo o momento aspectos de meu próprio percurso formativo. Nesse sentido, a utilização de narrativas também se faz importante, visto que é a partir delas e da utilização da memória que os estudos autobiográficos se concretizam. Entrevistas com o professor supervisor e pibidianos do grupo também foram realizadas. Durante todo o período da pesquisa também foi e está sendo realizado um levantamento bibliográfico acerca dos principais temas desse trabalho.

\section{Resultados e Discussão}

Acredita-se, a partir da Teoria do Discurso (LACLAU, 2011) que os professores supervisores e os pibidianos representam particularismos distintos, com suas demandas e especificidades próprias, que apresentam enquanto corte antagônico seus diferentes espaçostempo de formação. É inerente a esse quadro, portanto, a existência de tensiosamentos entre o professor supervisor e demais pibidianos. Tensiosamento esse que não está sendo qualificado em nenhuma categoria negativa ou positiva, mas sim apresentado enquanto uma dinâmica presente nas atividades pibidianas. Esses tensiosamentos caracterizam as articulações realizadas entre dois particularismos que buscam alcançar a condição de universal a partir de um discurso hegemônico, que é representado por seus processos distintos de formação docente.

\section{Conclusões}

A Teoria do Discurso aliada aos estudos de Formação Docente, apesar de densa e abrangente, tem se mostrado significativamente proveitosa para se alcançar os objetivos propostos. A mesma avaliação pode ser feita da metodologia adotada. Por ser uma pesquisa ainda em andamento novas variáveis podem surgir, bem como novos caminhos podem ser trilhados e novas compreensões possam existir dada à contingencialidade inerente às nossas próprias demandas enquanto pesquisadores.

\section{Agradecimentos}

Agradeço ao Ateliê de Pesquisas e Práticas em Ensino de Geografia (APEGEO) por todos os debates e orientações que em muito contribuíram para essa pesquisa.

LACLAU. Ernesto. (2011). Emancipação e Diferença. Rio de Janeiro: Eduerj, p. 220 . 